\title{
CENSORSHIP AND THE THEATER OF MANUEL BRETÓN DE LOS HERREROS
}

Gerard Flynn

\section{Fernandine Censorship}

On two occasions, at least, Manuel Bretón de los Herreros complained about the effects of censorship on his theater. In his Arte de la declamacion (1852) he had this to say about the period 1823-1833, the last ten years of the reign of Ferdinand VII, and 1833-1843, the decade of "re-establishment of public liberties," following Ferdinand's death:

Dado el impulso, ya no se cejó en él un solo instante, y coincidiendo el restablecimiento de las libertades públicas con la ilimitada de la escuela llamada romántica, importada también de los franceses, que la habían tomado de los alemanes, la poesía escénica tomó en Castilla un vuelo portentoso y ostentó una actividad febril que la expusieron a morir de plétora, como antes había muerto de inanición. ¿Qué mucho, si de pronto sacudió el yugo de la censura frailera y el de las terribles y tiránicas unidades, rémoras del talento y verdugos de la imaginación?... ${ }^{1}$

The key to the theatrical inanition of the years 1823-1833 is the phrase "el yugo de la censura frailera," which may be construed as "absolutist censorship." Although Bretón had to write for the censor throughout his entire career [his last work, Los sentidos corporales (1867) being approved by the official theater censor, Narciso Serra ${ }^{2}$ ], after 1833 the scrutiny of the plays was not friarly; the new censors belonged to a non-absolutist species.

Bretón's most definitive statement on censorship appears in a footnote he wrote to the 1850 edition of his play, El Ingenuo, which was first staged in 1828, five years before the death of Ferdinand VII. The footnote reads:

Esta comedia, sin duda la más débil de la colección, fue escrita en pocos días, y su argumento no era para tratado cuando sobre el teatro y sobre la imprenta pesaba una censura sobrado rigorosa y suspicaz. Mostrar de relieve los inconvenientes de la veracidad exagerada, sin poner en boca del protagonista verdades muy de bulto, que produjesen consecuencias trascendentales, era lo mismo que abortar, por decirlo así, un pensamiento cómico que merecía dilucidarse con más holgura. El autor hubo de imponerse, al desenvolver el carácter del Ingenuo, iguales o mayores miramientos que los que las leyes de la culta sociedad aconsejan y de esta mismo fábula se desprenden. Forzosamente había pues de resultar incompleto el tipo e ineficaz la lección. El Pleraque differat et praesens in tempus omittat de Horacio le perseguía al formar su plan y al desarrollarlo en el diálogo. ${ }^{3}$ 
Bretón was noted for his comic muse and festive air, which are frequently mentioned by his contemporaries and by later critics of the nineteenth century. ${ }^{4}$ A careful examination of El Ingenuo in the light of the footnote just cited will show the awesome power of "friarly censorship" over Bretón as a comediographer; it will also show the effect censorship has on laughter, which, as George Meredith and Henri Bergson have pointed out, is a social phenomenon.

El Ingenuo was first staged at the Cruz theater on November 13, 1828, and twenty-two years later Bretón added to it his footnote on censorship. First the note says:

Esta comedia, sin duda la más débil de la colección, fue escrita en pocos días...

Bretón obviously thought little of El Ingenuo and before his death in 1873 he omitted it from his document, "Plan Para Una Nueva Edición De Mis Obras"; 5 to be sure, it did not appear in the large five-volume edition of the collected Obras in 1883. Nevertheless, the literary critic may take exception to Bretón's judgement. The play is not as bad as he seems to think, and one can only conjecture that when belittling it he had in mind what he might have accomplished had the censor not stayed his hand.

Bretón writes:

...su argumento no era para tratado cuando sobre el teatro y sobre la imprenta pesaba una censura sobrado rigorosa y suspicaz.

The fact of "friarly censorship" appears here, but it is not immediately clear to the reader why it weighed so heavily on El Ingenuo rather than, say, Marcela, one of his most famous plays, which was staged on December 30, 1831, just three years later. On reflection, however, the reader perceives a lifting of the veil.

In Bretón's early theater, nothing of possible public controversy appears, in religion, politics, or economics; all strife and conflict are reduced to the family, where they center around the marriage of a young man and woman. ${ }^{6}$ Humor under the "friarly censorship" of 1823-1833 was solely domestic. In the case of Marcela, both the plot and humor are naturally associated with the family, since they concern a beautiful young widow who holds three suitors at the end of a string. Censorship is redundant with respect to Marcela, merely limiting a domestic comedy to the scope of the family, where it would remain even if there were no coercion. This explains why Marcela is the most acceptable of Bretón's early works: he was writing as Bretón and not as Breton-with-thecensor-at-his-side. El Ingenuo, on the other hand, has a broader theme, namely, the effects of indiscreet veracity, and misanthropy, on the person in whom they reside and upon his victims. Although such a theme may include the family, it need not stop there but may also encompass prelates, merchants, and ministers of state; indeed, it is open to persons of all stations, so that coercion of any kind restricts the artist in his work.

The next lines of Bretón's footnote, from the words "Mostrar de relieve los inconvenientes de la veracidad exagerada..." to the Latin phase quoted from Horace, contain the heart of the matter, because here Bretón the artist tells in a few choice words how censorship hurt his play; in effect, he explains how it hurts all comic works of art in the theater. Thus it is a universal statement written by a practical man ${ }^{7}$, the artist, which philosophers might consider in their studies on aesthetics. The key phrase is "verdades muy de bulto." 
In Acts I and II of El Ingenuo Don Ramón speaks out bluntly on five occasions to each of five other characters in the play, insulting them with the naked truth (which arises from his "veracidad exagerada"). His first vic ...n is the avaricious Don Zoilo, who seeks a wealthy husband for his daughter. Flattering Ramón, Don Zoilo's fulsome praise accumulates so many adjectives it becomes comical:

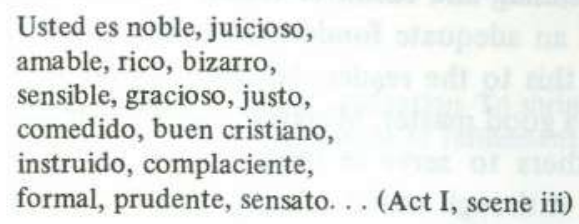

An aposiopesis appears in the text after sensato, for Don Ramón cuts him short. The audience can see, and the reader imagine, the graceless miser caught off balance, on tiptoes and stammering, his beard trembling, with another string of epithets in his teeth. $\mathrm{He}$ is a fantoche, a marionette dangling from a string, a figure from the Italian commedia dell'arte, and as such he is most emphatically funny.

The same kind of humor, which Henri Bergson associates with mechanical rigidity or inelasticity (raideur mécanique) ${ }^{8}$, takes place when Don Ramón tells his rival, Don Jorge, that they are not kindred spirits:

Don Ramón: es mi amigo? $\quad \begin{gathered}\text { ¿ Usted } \\ \text { ¿ }\end{gathered}$

Don Jorge: Nos vemos a todas horas.

Don Ramón: Sí; pero no congeniamos.

Don Jorge, trying to be nice to the misanthropic Ramón, has been speaking of friendship, but the latter with his bluntness catches him off balance too, and the audience laughs (Act I, scene v).

Ramón's frankness with Teresa in Act I, scene vii, is also comical, as is his artless way in Act II, scene v, where he tells the disdainful - or allegedly disdainful! - Casilda that she does indeed like men!

The last target of Ramón's candor is the poetaster, Don Matías, who shares the comic laurels of the play with the miser, Don Zoilo. Act II, scene vii of El Ingenuo is the quintessence of Moratín's La comedia nueva. ${ }^{9}$ Don Matías exclaims:

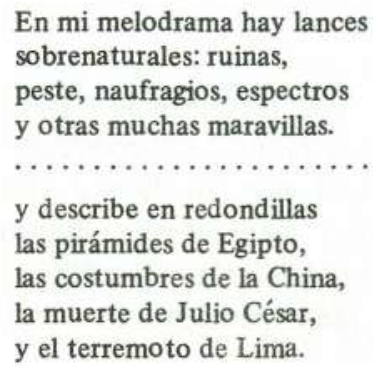

En mi melodrama hay lances sobrenaturales: ruinas, peste, naufragios, espectros y otras muchas maravillas.

$y$ describe en redondillas las pirámides de Egipto, las costumbres de la China, la muerte de Julio César, y el terremoto de Lima. 
Don Matías is Folly's own author, her favorite son. He is a risible animal, and so are we, his audience. ${ }^{10}$

It becomes clear now what Bretón meant when he said he wanted to place prominent truths (verdades muy de bulto) in Don Ramón's mouth but was unable to do so. In El Ingenuo he hoped to demonstrate "the disadvantages of excessive veracity," which is a question of meaning and form, or fondo y forma as Hispanists often say. But censorship denied Bretón an adequate fondo. In his footnote of protestation he seems to be saying something like this to the reader, between the lines: . . . . . My hands were tied by the censor. I had a good master, Moratín, and also the comedies of Lope, Moreto, Ruiz de Alarcón and others to serve as models. ${ }^{11} \mathrm{I}$ had the form, the vessel of the comedia, firmly in hand. Although noted for my festive air, I was no mere mery-andrew, as some people seemed to think. ${ }^{12}$ I was prepared to write a series of comedies worthy of Molière, and as he taught France in the seventeenth century so I would teach Spain in the nineteenth. I was on the threshold of a great theater rather than a theater of merely's: instead of Don Zoilo being merely a greedy father eager to wed his daughter, I might have made him a greedy father and disciple of Jeremy Bentham, who would see the greatest happiness of all in a wealthy son-in-law! Or I might have made him a grimacing afrancesado of exaltado, or a rigid abolitionist of hall taxation (!), or an absent-minded mock-heroic Carlist, a classical miles gloriosus, a study in permanent, quixotic distraction. Or I might have used the well-known lines of Feijoo:

Busco en los hombres aquel amor de la patria que hallo tan celebrado en los libros; quiero decir aquel amor justo, debido, noble y virtuoso, y no le encuentro.

- I might have used these lines and shown a disciple of Calomarde lining his pockets in the name of San Fernando and Spain! Don Zoilo was foolish in my play, and very funny, but I might have made him doubly foolish and funny with "prominent truths" such as those just mentioned. In 1828 , however, these truths would not have passed the censor. Some critics, Larra included, ${ }^{13}$ have accused me of repeating the same theme and even the same plot in my plays, but I Bretón ask you, what option did an author have in the decade 1823-1833? I later wrote plays of a disputatious nature, e.g., La redacción de un periódico, in 1836; Flaquezas ministeriales, in 1838; and El editor responsable, in 1842; but before the death of Ferdinand in 1833 one did not write plays such as these because:

\section{...su argumento no era para tratado cuando sobre el teatro y sobre la imprenta pesaba} una censura sobrado rigorosa y suspicaz.

The same line of reasoning may be applied to the other characters of El Ingenuo. Don Ramón, with his exorbitant candor, might have been a radical from the provinces, or like Bretón, a military man with some terrible truths, comical truths, to utter about the army. Don Jorge, his rival in love, might have played his socio-political opposite, or perhaps Don Zoilo's opposite. The redoubtable Casilda, disdainful of men, might have been a classic mujer brava constantly and comically repeating some dictum of the reactionaries against a facile and wooden Teresa, the flirt, who might similarly have repeated and echoed the critical dicta of the philosophes. Bretón's choices, without censorship, would have been innumerable. Don Matías, the ridiculous poetaster, might have been elevated to another rank, perhaps that of a Comella publishing an outrageous newspaper or broadsheet. 


\section{Fernandine Censorship and the Philosophers}

The study of "friarly censorship" and Bretón's theater throws a dismal light on the history of Spain in the first third of the nineteenth century. It has been said that laughter is a social gesture, an affirmation of shared values. ${ }^{14}$ The philosophers also speak of it as a desirable corrective for society; George Meredith, for example, mentions the "vigilant sense of collective supervision"; then he says:

Sensitiveness to the comic laugh is a step in civilization. To shrink from being an object of it is a step in cultivation. We know the degree of refinement in men by the matter they will laugh at, and the ring of the laugh. ${ }^{15}$

Meredith's ideas are in keeping with those of Henri Bergson, who remarks:

Consequently the comic expresses an individual or collective imperfection which calls for an immediate corrective. This corrective is laughter, a social gesture that singles out and represses a special kind of absent-mindedness in men and events. ${ }^{16}$

Here is the dismal light. If the reader accepts Meredith's opinion, he must admit that the Spaniards of the 1820's often laughed at trivia, which Breton himself called "bread and circuses." 7 This discloses something about their "degree of refinement" at the time or their "step in civilization." If the reader accepts Bergson's opinion, he will conclude that owing to censorship the "social gesture" and "corrective" known as laughter was wanting in the Spanish theater between 1823 and 1833. Had Breton been unfettered, he alone could have provided the corrective, but he was not free, because "sobre el teatro... pesaba una censura sobrado rigorosa y suspicaz."

Two more statements of Bergson, when applied to Bretón's theater, reveal the nature of censorship:

(1) Now step aside, look upon life as a disinterested spectator; many a drama will turn into a comedy. ${ }^{18}$

(2) You would hardly appreciate the comic if you felt yourself isolated from others. Laughter appears to stand in need of an echo. ${ }^{19}$

There is a paradox here. On the one hand, "step aside" (isolate yourself) and dramas will turn into comedies; on the other, do not be isolated and both you and others will laugh. The apparent contradiction is resolved if one reasons that stepping aside, or isolation, refers to the author, whereas the non-isolation or social communion refers to the audience.

Censorship, as Bretón knew it before 1833, destroys both halves of the paradox. Under "friarly censorship" a playwright cannot step aside and be by himself, turning dramas into comedy, for everything in life is made a moral issue, incapable of being humorously treated. In the theater, people are allowed to laugh only at domestic incongruities or similar situations, which ordinarily must be contrived by the non-isolated author. Conversely, under absolutist censorship people cannot band together, form a viable audience and laugh at an object of common ridicule. All persons are isolated 
vis-à-vis the censor, so they cannot correct him or the things he cherishes with their mirth; thus censorship destroys society. In his own eyes the censor needs no correction. He is incorrigible. ${ }^{20}$

Bretón was a good comediographer. If his early plays seem at times trivial, as some critics have observed, the defect came honestly and truly from outside his own talent. He was hampered by a censorial tub. ${ }^{21}$

\section{Post-Fernandine Censorship and Two Plays of Bretón}

To the casual reader, censorship after 1833 might seem as rigorous as censorship before that year. The "Reglamento que ha de observarse para la censura de los periódicos," of January 4,1834 , seems extremely severe:

... los censores no permitirán la publicación de escritos contra la Religión, la Monarquía o las Leyes fundamentales; ni de los dirigidos a excitar a la rebelión; ni de los que estimulen a infringir alguna Ley o a desobedecer a alguna Autoridad; ni de los "licenciosos y contrarios a las buenas costumbres"; ni de los injuriosos o infamatorios para personas privadas; ni de los que injurien a "Soberanos y Gobiernos extranjeros o exciten a sus súbditos a la rebelión." 22

To all appearances, these regulations seem absolute. A phrase such as "licentious and contrary to good customs" provides enough breadth to prohibit the printing of anything the censors deem inimical.

That censorship continued to have a rigorous, and ostensibly an absolute, nature may also be seen in the pages of an American traveler, Mr. Severn Treackle Wallis, who wrote in 1853:

The freedom of the press in Spain is guarantied... by an express provision of the constitution, which ordains that it shall suffer no restrictions but those to be imposed by law. .

This constitutional guarantee had been abused, which induced, in 1848, the Minister of the Interior Sartorius to come up with a scheme of reform. Mr. Wallis did not see the scheme, but he was informed:

... that it abounded in excellent sentiments, and extended unlimited freedom to all publications in which there might be no discussion of religion or morals, politics, manners, or legislation. ${ }^{23}$

This clause apparently goes beyond the "contrary to good customs" clause cited above, for one need not even offend good customs and manners in order to receive official disapprobation, but merely be disposed to discuss them. Furthermore, outside of "religion or morals, politics, manners, or legislation," what else is there? Were Spanish authors to have "unlimited freedom" to discuss nothing?

Perhaps the reality of post-Fernandine censorship, as opposed to the censorship appearing in written law, had best been studied in two plays of Manuel Bretón de los Herreros, namely, La redacción de un periódico (1836), and El editor responsable (1842). 
The content of these plays will show that censorship changed a great deal in practise after 1833. Since they were staged within the decade following Ferdinand's death (1833-1842), they serve as a good balance for the plays of Bretón's early period (1824-1833).

La redacción de un periódico (1836)

La redacción de un periódico contains the Moratinian-Bretonian plot of a young couple opposed to the senex figure. ${ }^{24}$ Agustín and Amelia want to get married, but her father, the newspaper proprietor, wants her to visit an aging, sick, childless uncle in Santander in order to insure her getting the inheritance.He also plans to marry her to the son of another uncle, a successful merchant. In the end, true love is victorious.

La redacción de un periódico, however, does not keep to the former Bretonian mold since its author now places several prominent truths (verdades muy de bulto) in the mouths of his characters. First of all, the editor, Don Fabricio, envies the economic security of yesteryear:

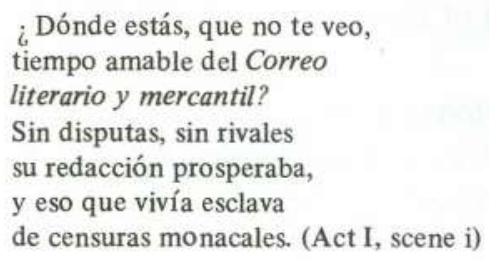

Friarly censorship was bad and the throne may have cast a pall over society, but at least there was financial prosperity for the one or two newspapers allowed to exist in Spain. The new rivals and "plaga de publicistas" demonstrate for the reader not only an economic struggle for newspaper proprietors but also a relaxation of censorship. Jornalism grew because public opinion grew and became variegated; hence the disputes and the fact that all the "muchachos de colegio" wanted to take pen in hand. The phrase "vivía esclava de censuras monacales" also indicates that whatever restraints were still in existence in 1836 were non-monastic, that is to say, non-absolutist.

Don Fabricio continues his speech, giving an historical account of the years 1833-1836:

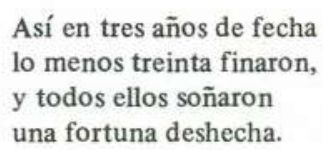

Once again the play stresses the economic side of the picture; newspaper men were as much concerned about money as news (a preoccupation surely not confined to the 1830 's). Fabricio names some twenty-seven papers that failed during the triennium, and his list is unquestionably historical for twelve of them are listed in the index of a recent Historia del periodismo español, and the other lesser-known journals have namesakes from an earlier or later period. ${ }^{25}$ With names like El Boletin de Comercio and La Abeja sounding in the audience's ear, Fabricio's list is quite convincing. 
The words of Fabricio, as he reads his list, suggest that ministerial chicanery was a substitute for absolutist censorship:

$\begin{aligned} & \text { El venerable Correo } \\ & \text { murió de un golpe de estado; }\end{aligned}$
$\ldots \ldots \ldots \ldots \ldots \ldots \ldots$
Murió eclipsada la Aurora
víctima de un mandarín,
$\ldots \ldots \ldots \ldots \ldots \ldots$
El rayo ministerial
abrió un mismo panteón
al Eco de la Opinión,
al Tiempo, al Universal
y al Cínife... 26

This implication of chicanery is in keeping with the plot of La redacción de un periódico, in which Don Tadeo ${ }^{27}$ is persuaded to publish a pro-ministerial editorial by a promise to enter him on the government's payroll; hitherto he had run anti-ministerial leaders in the hope of causing sensation and increasing sales. Thus the newspapers themselves were guilty of chicanery, the kind of slyness that did not and could not exist under absolutist censorship.

The censorship regulations of 1834 , referred to above, forbade the publication of writings "licenciosos y contrarios a las buenas costumbres" and also those that were "injuriosos o infamatorios para personas privadas." But in Bretón's play, Fabricio says:

Hablada de ese periódico

que con tanta avilantez

nos injuria. (Act I, scene iii)

The avilantez of this fictitious newspaper, a mirror of reality, implies that the law of 1834 was being violated. Consequently, the censorship statutes must have been more elastic than they appear at first glance.

At the end of the first act of La redacción de un periódico many subscribers come to the office to cancel their subscriptions, but one man, Antonio Pérez, plans to sign a subscription providing the editors print a certain article denouncing the Ministry. Don Tadeo, who is supposed to run a neutral newspaper, agrees to publish it, saying:

Se pondrá. (Así como así

con defender al Gobierno

no he de medrar.) (Act I, scene vi)

Since Don Tadeo will support or oppose the government to suit his pocketbook, this passage clearly shows the limited nature of post-Fernandine censorship as it appears in Bretón's theater; one cannot imagine one of Ferdinand's friarly censors countenancing the whimsical support of the government. This passage also shows the roguish nature of the newspaper business. ${ }^{28}$

In the second act of La redacción de un periódico one perceives that verdades muy de bulto ("prominent truths": the vicissitudes of the newspaper world) lead to broader 
comedy and costumbrismo. An actress comes to the editorial room to complain about the theater reviewer, who has called her old, an interdicted word for the ladies; in the ensuing argument the words adulta and adúltera and Silva and silba are most unhappily confused. When Agustín flatters the actress in order to appease her, his beloved Paula begins to question his fidelity. A fierce captain of guerrilleros comes to challenge the editor to a duel. Fabricio is frantically translating articles from the French, to fill out a column, and one imagines him surrounded by ever-mounting tons of foolscap ${ }^{29}$, but there is still insufficient material for this illustrious journal. A poet submits some detestable verses, and the exigent printers' foreman comes to pick up the copy for print. All these scenes lend a fulness to La redacción de un periódico that is completely wanting in an earlier play such as El Ingenuo: there is also reference to the Carlist civil war in the north.

The entire second act, moreover, is a cuadro de costumbres within which the dramatic family conflict of Paula and Agustín with her father continues. And one learns something explicit about the daily edition of a newspaper:

$\begin{array}{cl}\text { Agustín: } & \text { ¿Falta mucho para el número? } \\ \text { Regente: } & \text { Aun está en paños menores; } \\ & \text { digamos ...... } \\ \text { Agustín: } & \text { Lo así. No importa: } \\ & \text { la Gaceta de esta noche } \\ & \text { nos dará un par de columnas; } \\ & \text { luego enviarán los censores } \\ & \text { más materiales: con esto } \\ & \text { y con la sesión de Cortes, } \\ & \text { la Bolsa y los espectáculos, } \\ & \text { hay sobrado ...... (Act II, scene v) }\end{array}$

With the materials just mentioned, and with the hastily translated ripios of Fabricio from the French, Agustín will publish the distinguished and illustrious newspaper of Don Tadeo.

Later in Act II, Don Tadeo so speaks of censorship that the reader can clearly see room for a variety of opinions before the government, including opposition:

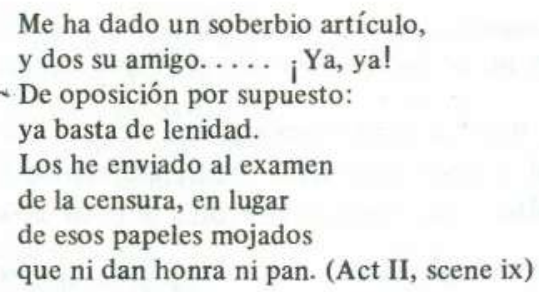

The papeles mojados bringing neither honor nor bread are the impartial articles written by Agustín and his colleagues, who seek to publish the truth; but Don Tadeo is interested only in bread - money - and is willing to engage in histrionic opposition to win it.

With respect to censorship, La redaccion de un periódico presents the critic two realities: (1) the reality of the playwright himself, Breton, which is the flesh-and-blood reality of the reader, and (2) the reality of the characters in the play, Fabricio, Agustín, Don Tadeo, and others, which is the reality of Don Quixote and Sancho as they insist on 
a true history. Within the reality of Bretón's world, La redaccion de un periódico passed censorship in 1836 in spite of its indicating that both the government and its official censors are venal and temporizing; no similar indication would have passed the friarly censorship prior to 1833. Within the reality of the play, Don Fabricio and the other characters act as if the censorship of 1836 were qualified rather than absolute: I construe their attitude to be a true history, a faithful mirror of the day.

\section{El editor responsable (1842)}

Censorship assumes responsibility or accountability. If the ordinances of the censor are broken, some person or corporation must be held accountable so the censor can exercise sanctions against him, usually in the form of a fine or prison sentence. Some of these sanctions can be seen in La redacción de un periódico, where fines are mentioned on several occasions, for example:

\begin{tabular}{lc}
$\begin{array}{l}\text { Fabricio: } \\
\text { Tadeo: }\end{array}$ & ¿ Y está censurado? \\
Fabricio: & Pues $i$ cómo se ha de imprimir.....? \\
Tadeo: & No importa. \\
Fabricio: & \multicolumn{2}{c}{ Si lo denuncian } \\
& al Gobernador civil, \\
& la multa.... (Act IV, scene vi)
\end{tabular}

In Spain, from 1834 to 1868 , a person known as "el editor responsable" was added to the staff of each newspaper; responsibility, that is, legal accountability, was his only reason for existence. Others might write or edit an article, perhaps inflammatory in tone, but he was the one who signed each number of the newspaper and if a case went to court it was he who stood in the dock and had to answer all charges. Since his accountability might be reckoned as a two year sentence in jail, the office of editor responsable was extremely risky. This legal personage might better have been called "the scapegoat editor”, and Prime Minister Cánovas had this to say of him and his breed:

... por precio vivían (nuevo género de esclavitud) bajo el peso de una serie interminable
de condenas por delitos que no habían cometido ni podido cometer. 30

As in all risky jobs, there were always openings for new editors responsible, and the pay was high, which attracted young men who might otherwise be unemployed. This well defined verdad muy de bulto is the basis of Bretón's play of 1842 .

The plot of El editor responsable resembles that of Muérete ${ }_{j} y$ verás!, which had appeared in 1837. Josefine, a coquette, and Ana, a stable young lady, work together as seamstresses. Josefina has both Gaspar and Dupré on a string, whereas Ana loves only Gaspar. Dupré writes an inflammatory article against the government for El Terremoto, but it is Gaspar, the editor responsible, who may have to do a two year stint in jail for this action. At the end of Act I the fickle Josefina forsakes Gaspar for Dupré (Gaspar is dead to the world, so to speak, like Pablo in Muérete $; y$ verás!). Dupré has used Romantic language! $\mathrm{He}$ has threatened dramatic assassination and suicide! $\mathrm{He}$ has conquered her! ${ }^{31}$ 
Once again, this comedy displays a far greater wealth of ideas, customs, and humor than the plays of 1824-1833. The day of Gaspar's trial, the scene in the waiting chamber of the courtroom, where the crowd makes fun of the portero, is one of the most comical Bretón ever penned:

Portero: Para todos soy severo, mas para ella..... ¡ Pobrecita!

i Tan guapa..... Homo sum! No quita

lo cortés a lo portero.

Ciud. 3. $^{\circ}: \quad$ ¿Habéis oido? Homo sum!

Ciud. $1 .^{\circ}$ : Pues lo afirma, lo creeré, pero yo dudaba. ....

Ciud. $3^{\circ}$ :

Ciud. $10^{\circ}$ : ¿Qué?

Portero:

Ciud. 2. ${ }^{\circ}$ :

Si era hombre, o si era atún.

Portero:

¡ Dudar de mi especie! ¡ Voto......!
Tengamos la fiesta en paz.

O seré capaz. ...

Ciud. 2. ${ }^{\circ}: \quad$ Y hablemos de El Terremoto. (Act II, scene xi)

With the mention of the inflammatory newspaper, El Terremoto, the play returns naturally and gracefully to its prominent truth: will an innocent young man, an editor responsible, be sentenced to prison for the indiscretion of others? This graceful turning from humor to a weighty truth and back again to humor did not appear in Bretón's early theater, which was bound by absolutist censorship.

One will not forget the love scene of Gaspar and Ana (Act II, scene xvii), or Gaspar's soliloquy right after it:

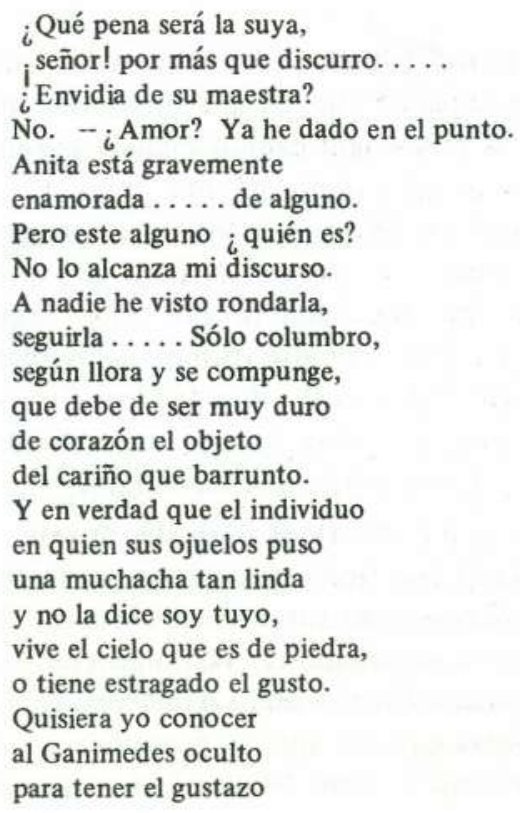


de decirle que es un bruto. -

Pero....., si bien reflexiono.....,

la sensación que produjo

en su pecho la noticia

de mi casamiento; el sumo

interés con que ha mirado

el inminente infortunio

de que acabo de librarme

por milagro; tantos pujos

de llorar cuando me mira;

y callar cuando pregunto

la causa de su dolor,

o responder con singultos. ....

Me atrevería a apostar,

y no sería un absurdo,

a que yo soy el narciso

de cuyo desdén injusto

se lamenta. Sí, yo soy

el que acelera su pulso;

yo soy el galán incógnito;

yo soy la piedra. .... ${ }_{i}$ y el bruto! (Act II, scene xviii)

Later in the play a colonel somes to challenge the editor responsible to a duel: duelling is another facet of this comedy's verdad muy de bulto. At the end, after Gaspar's acquittal of the charges against him, the government buys off Dupré with a 5000 franc bribe. ${ }^{32}$ True love wins out. Gaspar will marry his beautiful and faithful Anita. ${ }^{33}$

\section{A Conclusion Concerning Censorship}

Manuel Bretón de los Herreros complained occasionally about the effects of censorship (censura frailera) on the Spanish theater and on his own theater in particular. Such censorship causes inanition. A playwright cannot include prominent truths (verdades muy de bulto) in his plays, with their transcendental consequences, and as a result "his characters are incomplete and his lessons inefficacious." A given author, Bretón himself for example, may understand the censorial mold and produce a somewhat entertaining, light-hearted theater, but the hand of the censor weighs on everything, affecting not only the content of the play but also its mode of expression. Bretón's own plays stand in proof of this statement, for after the diminishing of censorship in 1833 and 1834 they became broader comedy: their humor became more diverse, their customs or manners more widespread, and their love poems more memorable.

Absolutist censorship hampers the liberty of both the private citizen and society. One playwright cannot isolate himself and freely ponder the shortcomings of his country thereby converting apparently dramatic events into comedy, because the censor, himself a dramatist of sorts, views everyhing with solemnity. National events are his drama and scarcely a subject for the comic muse. On the other hand, one spectador cannot unite himself to other spectators and form a risible society mocking common faults, because the censor will not brook such laughter, the most telling of all corrections. 
The absolutist censor represents perfection ${ }^{34}$ and consequently is incorrigible; as the custodian of religion, politics, and economics he cannot permit the existence of a comedia corregidora. Since the end of comedy is the correction of two parties, the old and the vicious ${ }^{35}$, the censor will permit only a kind of half-comedy. Thus in Fernandine Spain, Bretón could correct only the old members of a family, the senex figures of ancient comedy, and having to do this over and over again he left himself open to the charge of superficiality. Two of Bretón's post-Fernandine plays about the newspaper world clearly show that this alleged weakness on his part is founded on censorial constraints rahter than lack of native talent. His later plays are good comedies, deserving a more reflective criticism than they have generally received. Breton, the finest Spanish playwright of the nineteenth century, had the art of gracefully turning from humor to prominent truths and back to humor again. His love stories are delightful, and in portraying the society of three decades he is Spain's Balzac. ${ }^{36}$

\section{Department of Spanish and Portuguese}

The University of Wisconsin

Milwaukee - USA

\section{NOTES AND REFERENCES}

${ }^{1}$ See Bretón, Obras escogidas, 2 volumes (Paris: Baudry, 1853), I, xxxvi; the full title of the essay is Progresos y estado actual del arte de la declamación en los teatros de España. The question of the unities as a form of censorship, or restraint, would make an interesting study in itself; according to Eric Segal, Plautus faced the same obstacle of censorship and unities as Bretón: see Segal, Roman Laughter (Cambridge: Harvard U. Press, 1968), p. 9.

${ }^{2}$ See Los sentidos corporales (Madrid: Imprenta de José Rodríguez, 1867), p. 93. Serra's appointment as censor seems in keeping with the canon's advice in the 1605 Quixote, Ch. 48.

${ }^{3}$ Bretón, Obras, 5 volumes (Madrid: Imprenta Nacional, 1850-1851), I, 161.

${ }^{4}$ See the Marqués de Molíns, Bretón de los Herreros, recuerdos de su vida y de sus obras (Madrid: Imprenta de M. Tello, 1883), pp. xiii, 163. See also the prolongue of Hartzenbusch to the Obras escogidas of Bretón, I, xiv.

${ }^{5}$ Obras, 5 volumes (Madrid: Imprenta de Miguel Ginesta, 1883-1884), I, lxii.

${ }^{6}$ In Achaques a los vicios, the conflict arises among a vain wife, gluttonous mother-in-law, and gambling husband; this conflict takes place after marriage.

${ }^{7}$ I use "practical man" in the sense of "Bretón-the-playwright." See Harold Rosenberg, "The Profession of Poetry and M. Maritain," in The Tradition of the New (New York, 1965), pp. 96-120.

${ }^{8}$ Concerning Don Zoilo's humorous repetition of adjectives, see Henri Bergson, Laughter (Garden City: Doubleday, 1956), pp. 67, 107, 120-122.

9 Although Bretón's early, Moratinian, plays passed censorship, Moratín's own plays were not staged for more than ten years. See A. Rumeau, "Le Théâtre à Madrị à la veille du Romantisme, 
1831-1834," in Hommage à Ernest Martinenche, Êtudes hispaniques et americaines (Paris: Éditions Arbrey, 1939), p. 341.

${ }^{10} \mathrm{I}$ am using risible in the double sense of he who laughs and he who is laughed at. See Bergson, op. cit., p. 62.

${ }^{11}$ By 1828 Bretón had already made adaptations of Lope, Calderón, and Moreto, and he re-cast a play of Ruiz de Alarcón in 1829: he was well versed in the classical theater of Spain. By 1828 he had likewise translated the plays of Molière, Marivaux, and other French playwrights.

${ }^{12}$ Apparently the merry-andrew accusation is the fate of all comediographers, even of an author such as Molière. See F. Brunetière, Brunetière's Essays in French Literature (New York: Scribner's, 1898), pp. 66-72.

${ }^{13}$ See Molíns, op. cit., Ch. XIII.

${ }^{14}$ See Eric Segal, Roman Laughter, cited in note 1, above. This is an important book for the student of Bretón, since much of what Segal says of Plautus can be predicated of him.

${ }^{15}$ George Meredith, An Essay on Comedy (Garden City: Doubleday, 1956), pp. 50-52.

${ }^{16}$ Bergson, op. cit. p. 117.

${ }^{17}$ See "Cuatro consejos a un poeta dramático bisoño," in Bretón's Obras of 1850-1851, Vol. V, p. 615: "El público no limita ahora sus goces al pan y circenses con que en la década ominosa se contentaba..."

${ }^{18}$ Bergson, op. cit., pp. 63-64.

${ }^{19}$ Bergson, loc. cit.

${ }^{20}$ There is no comedia corregidora, which is tantamount to saying there is no comedia. A perfect illustration of censura frailera appears in Molín's biography of Bretón, pp. 46-47. See also Sterling Stoudemire, "Gil y Zárate's Translations of French Plays," Modern Language Notes, XLVIII (1933), p. 321 .

${ }^{21}$ See Juan Goytisolo's article, "Writing in an Occupied Language," New York Times Book Review, March 31, 1974, p. 47.

${ }^{22}$ See Pedro Gómez Aparicio, Historia del periodismo español (Madrid: Editora Nacional, 1967), pp. 195-196.

${ }^{23}$ Severn Treackle Wallis, Spain. Her Institutions, Politics and Public Men. (Boston: Ticknor, Reed and Fields, 1853), pp. 82-83. Wallis's Chapter IX concerns the press and newspapers, his Chapter $\mathrm{XIX}$ the theaters and dramatic literature.

${ }^{24}$ See James L. Calderwood and Harold E. Tolliver, Perspectives in Drama (New York: Oxford U. Press, 1968), pp. 163-176.

${ }^{25}$ Bretón himself wrote for the Correo literario y mercantil: see the articles in his Obra dispersa (Logroño: Instituto de Estudios Riojanos, 1965). And see Fernando José de Larra, La sociedad española a través del teatro del siglo XIX (Madrid: Ministerio de Trabajo, 1947), p. 23; and Pedro Gómez Aparicio, op. cit., pp. 605-613.

${ }^{26}$ The plays of Bretón frequently display an onomastic joy similar to that of Galdós's novels; witness, for example, this list of newspapers.

${ }^{27}$ The name Don Tadeo calls to mind the real-life Don Francisco Tadeo Calomarde, whose servile ways were similar. Perhaps this likeness is not accidental and Bretón is calling on every resource at his command to reproduce the atmosphere of the period.

${ }^{28}$ Manual Tamayo y Baus, a Carlist, complains about the vile nature of newspapers in his moralizing plays of the 1850 's and 1860 's. And in $1853 \mathrm{Mr}$. Severn Treackle Wallis wrote: "“While I was in Madrid, it was a frequent occurrence for the whole daily edition of an opposition paper to be seized by the police, as it was upon the point of distribution, - some disagreeable expressions in an 
editorial article, perhaps, being the offence alleged. During Holy Week, when there were fierce rumors of dissensions at the palace and an impending ministerial crisis, four or five papers were "recogidos por orden de la autoridad", as it was politely called, in the course of a single day. Nobody seemed to think of it at all remarkable, and I will do the parties who suffered the justice (sic) to say, that they did not permit it to diminish the boldness and pertinacity with which they maintained and circulated their opinions. These encroachments on the privileges of the fourth estate were made, in due course, through the Department of the Interior." Wallis, op. cit., p. 83. Wallis's paragraph suggests that there was less censorship before the fact of publication than punishment after it.

${ }^{29}$ I was reminded of the Doctor in Benavente's guignolesque comedy, Los intereses creados, who was always shouting “ ¡ Escribid! ¡ Escribid!”

${ }^{30}$ There is a fine article on the editor responsable in the Enciclopedia Ilustrada of Espasa-Calpe, vol. 19, p. 91, which quotes Cánovas del Castillo's “preámbulo al Real decreto de 31 de Diciembre de 1876 ," the source of my quotation.

${ }^{31}$ Cf. Bretón's Muérete jy verás!, El editor responsable, and Rupert Allen, "The Romantic Element in Muérete ${ }_{j} y$ verás!,"Hispanic Review, XXXIV (1966), 218-227.

32 The play is set in Paris, a disguise perhaps to spare Bretón botheration with the authorities; if so, it is an extremely thin disguise for the only thing French about the play is the name Dupré and the mention of a bribe in francs. Such a comedy would not have been tolerated nine years earlier, in the days of Ferdinand VII.

${ }^{33}$ Concerning censorship, the reader might also study another play of Bretón, Flaquezas ministeriales (1838), which shows corruption amongst highly placed of ficials.

${ }^{34}$ Absolutism implies perfection, for the Absolute by definition is perfect. An absolutist king is God's temporal vicar on earth.

35 The vicious: specifically, the hypocrites. See F. Brunetière's essay on Molière, cited in note 12 above.

${ }^{36}$ I myself had seen a resemblance to Balzac before reading Georgs Le Gentil's passage likening him to the great Fench novelist; see Georges Le Gentil, Le Poète Manuel Bretón de los Herreros et la Société Espagnole de 1830 à 1860 (Paris: Hachette, 1909). James A. Corey disagrees with this idea; see Corey, The Comedies of Manuel Bretón de los Herreros, Doctoral Dissertation, UCLA 1972 (Ann Arbor: University Microfilms, 1973), p. 18. 